(d) The remaining 35 patients (70\%)-that is, those who did not suffer either of the complications-went home four to six weeks after the operation clinically cured-that is, completely continent (most patients) or suffering from only a very slight or occasional incontinence of which they made no complaint (a few patients).

\section{Pioneering Work}

We are indebted to Professor Ingelman-Sundberg, of Stockholm, and to Professor Martius, of Göttingen. Our technique borrows essential features from their pioneering work and we are very glad indeed to have this opportunity of recording our indebtedness to them both.

For nine years we have been using Martius's labial fatgrafting procedure in the repair of urinary fistulas not complicated by a total loss of the urethra. Seven years ago we read in Chassar Moir's (1956) Joseph Price oration that IngelmanSundberg had designed a remarkable operation in which the gracilis muscle was used as a pedicle graft directed through the obturator foramen into the upper vagina as a means of closing radium-produced bladder fistula.

Moir's report of Ingelman-Sundberg's brilliant work suggested to us that the solution to our problem-the totally destroyed urethra-might at last be found if we could combine the virtues of Professor Ingelman-Sundberg's muscle graft with those of Professor Martius's route. Two questions answerable only by a trial operation arose: (1) was the average gracilis muscle long enough to be directed into the vagina via Martius's indirect channel? and (2) if so would it provide the active muscular floor and walls of a reconstructed urethra?

The trial operation, undertaken in 1961, was happily a success. It gave favourable answers to both questions ; and many opera- tions of the same pattern since then have confirmed that the procedure does enable destroyed urethras to be soundly reconstructed with restoration of continence in the majority of cases.

Chassar Moir (1965), after seeing the operation in Addis Ababa four years ago, wrote: "The methods used by IngelmanSundberg and by Hamlin and Nicholson are essentially different. In the former the gracilis muscle is brought by a deep route to the upper vagina, where it provides a new blood supply and serves as a plug for the fistula; in the latter the muscle is brought by a superficial route into the lower vagina, where it provides a direct support to the bladder and urethral walls."

Our debt to Professor Ingelman-Sundberg and also to Professor Martius is obvious and great, and to them both we have expressed our gratitude earlier in this paper.

To two other fistula surgeons known throughout the world we are also much indebted-Professor Naguib Mahfouz and Professor Chassar Moir. In frequent letters over many years they have encouraged us and advised us in all our technical problems. Almost everything valuable about fistula surgery has been beautifully described or reported on in their writings. We salute them.

\section{REFERENCES}

Moir, J. Chassar (1967). Vesico-vaginal Fistula, 2nd ed., p. 108. London, Baillière, Tindall and Cassell.

Moir, J. Chassar (1965). Journal of Obstetrics and Gynaecology of India, 15,441 .

Moir, J. Chassar (1956). American fournal of Obstetrics and Gynecology, $71,476$.

Mahfouz, N. (1949). Atlas of Mahfouz's Obstetric and Gynaecological Museum, vol. 2. Altrincham, Sherratt.

Mahfouz, N. (1957). Fournal of Obstetrics and Gynaecology of the British Empire, 64, 23.

Last, R. J. (1954). Anatomy, Regional and Applied. London, Churchill.

\title{
Serum and Urinary Folate in Liver Disease
}

\author{
F. P. RETIEF,* M.D., D.PHIL., M.R.C.P. ; Y. J. HUSKISSON, † B.SC.
}

$S^{u}$ ummary : During the active phase of viral hepatitis urinary folate loss was found to be 8.0 to 48.3 (mean 31.1) $\mu \mathrm{g}$./day, compared with a normal urinary folate excretion of 0.1 to 18.0 (mean 9.5) $\mu \mathrm{g}$./day. In cirrhosis and cardiac failure with congestive hepatomegaly the corresponding values were 25.8 to 55.0 (mean 35.7 ) $\mu$ g./day and 2.5 to 61.6 (mean 26.9) $\mu \mathrm{g}$./day, respectively. Urinary folate loss may be a significant factor in the aetiology of folate deficiency of chronic liver disease, particularly when dietary intake is poor.

After prolonged dialysis in Visking casing urinary folate was almost totally dialysable, but an appreciable fraction of serum folate was not, even after 72 hours. The dialysable (free) folate fraction of serum and urine disappeared maximally during the first six hours' dialysis, and was virtually cleared after 24 hours' dialysis ; clearance curves in normal individuals and in liver disease were comparable. The non-dialysable serum folate fraction was of similar magnitude in all subjects studied, in spite of marked variation in total folate, and probably represented protein-bound folate.
The folate deficiency of liver disease is of multiple aetiology (Herbert, 1965). It is commonly the result of poor dietary intake, particularly in chronic liver disease associated with alcoholism (Herbert et al., 1963), while alcohol per se may increase folate requirement (Sullivan and Herbert, 1964). Haemolysis of chronic liver disease and erythroid hyperplasia secondary to haemorrhage from oesophageal varices causes increased folate demands (Klipstein and Lindenbaum, 1965). In cirrhosis enzymes essential for folate metabolism may be deficient (Carter et al., 1961 ; Merritt et al., 1962). In the adult folate is mainly stored in the liver in quantities of about 5-20 mg. (Chanarin et al., 1966). Hepatic dysfunction affects vitamin storage (Baker et al., 1964), and vitamin $B_{12}$, for instance, is liberated into the blood stream during liver disease (Stevenson and Beard, 1959). Vitamin $\mathrm{B}_{12}$ is effectively retained by plasma binders, resulting in significant urinary loss

* Head of Haematology Division, Department of Internal Medicine, Stellenbosch University Medical Schaol; Senior Consultant, Karl Bremer Hospital, Bellville, C.P., South Africa.

† Research Assistant, Haematology Division, Department of Internal Medicine, Stellenbosch University Medical School, Bellville, C.P., South Africa. 
only when the serum vitamin $B_{12}$ rises to particularly high levels (Retief et al., 1969). Little is known about binders of naturally occurring serum folates, but Metz et al. (1968) showed poor pteroylmonoglutamic acid binding by serum. It is thus conceivable that significant urinary loss of folate may occur when active liver damage floods the blood stream with storage folate. A temporary increase in urinary folate excretion occurs after surgical trauma, and this may be associated with a decrease in serum folate (Retief et al., 1968).

In the present project urinary folate loss was studied in acute and chronic liver disease. Serum and urine from normals and subjects with liver disease were also dialysed in Visking casing and the folate disappearance was measured in an attempt to show non-dialysable folate binders.

\section{Materials and Methods}

(1) Folate content of serum and urine was assayed by the aseptic addition method of Lactobacillus casei microbiological assay of Herbert (1966) ; normal serum folate for this laboratory is $3-25 \mathrm{~m} \mu \mathrm{g} . / \mathrm{ml}$. Twenty-four-hour urine samples were collected aseptically in Meredith disposable urine drainage bags. The total urine volume was measured, an aliquot taken, the $\mathrm{pH}$ adjusted to $7 \cdot 0$, and the sample stored at $-20^{\circ} \mathrm{C}$. Serial determinations showed that $L$. case $i$ activity of urine, refrigerated in this manner without ascorbic acid, did not decrease significantly during our maximal storage time of three months.

Urine and serum samples obtained on the same day were collected from 15 normal adults (on normal diets), 12 patients with acute hepatitis presumed to be of viral origin, eight with cirrhosis, and nine with hepatomegaly due to congestive cardiac failure. Antibiotics were avoided for at least 48 hours before onset of investigations. The patients with viral hepatitis were investigated at the onset of their illness, when their dietary intake was poor owing to epigastric discomfort and nausea. The subjects with cirrhosis and cardiac failure were on normal but salt-restricted diets; none were on high-protein intakes or vitamin supplements.

(2) One to two millilitre aliquots of urine and serum were dialysed in Visking casing ${ }^{1}$ against $0.9 \% \mathrm{NaCl}$ at $4^{\circ} \mathrm{C}$. for periods of $6,12,18,24,48$, and 72 hours. Sample volumes altered minimally during dialysis, though a slight decrease in volume was occasionally noted. It is thus very unlikely that ingress of saline could have caused significant dilution of folate values. The folate content of the dialysis bags were compared with those of control serum and urine samples kept in thin glass tubes under identical conditions at $4^{\circ} \mathrm{C}$. for 72 hours. No significant fall in folate was recorded in the controls.

(3) Vitamin $B_{12}$ determinations were performed on some of the serum and urine samples by the coated charcoal radiodilution assay of Lau et al. (1965).

\section{Results}

(1) The serum and urine folate levels of the various study groups are represented in Fig. 1. In normals the serum folate varied between 4.6 and 16.4 (mean 10.2 ) $\mathrm{m} \mu \mathrm{g} . / \mathrm{ml}$, and urinary folate between 0.1 and 12.8 (mean 6.8 ) $\mathrm{m} u \mathrm{~g} . / \mathrm{ml}$. In acute hepatitis the serum folate had a very similar mean value $(10.1 \mathrm{~m} \mu \mathrm{g} . / \mathrm{ml}$.) but wider range, while mean urinary folate increased markedly to $22.1 \mathrm{~m} \mu \mathrm{g} . / \mathrm{ml}$. $(\mathrm{P}<0.01)$. In cirrhosis the mean serum folate was not significantly lower than normal $(8.2 \mathrm{~m} \mu \mathrm{g} . / \mathrm{ml}$.$) , but the mean urinary folate level was$ prominently increased at $24.5 \mathrm{~m} \mu \mathrm{g} . / \mathrm{ml}$. (P<0 01). In congestive cardiac failure the mean serum folate was near normal, $6.7 \mathrm{~m} \mu \mathrm{g} . / \mathrm{ml}$., while mean urinary folate showed a significant increase at $17.0 \mathrm{~m} \mu \mathrm{g} . / \mathrm{ml}$. $(0.05>\mathrm{P}>0.02)$.

\footnotetext{
${ }^{1}$ Visking casing, 8/32 in. (6 mm.) diam:ter ; Union Carbide Corp., 6733 West 65 th Street, Chicago, Ill. 60638, U.S.A.
}

(2) Total folate loss in the urine over the 24-hour periods during which blood and urine were collected from each patient was calculated for the four study groups. In normal controls this was $0 \cdot 1-18.0$ (mean 9.5) $\mu \mathrm{g}$./day. In acute hepatitis it rose significantly to $8.0-48.3$ (mean $31.1 ; \mathrm{P}<0.01$ ) $\mu \mathrm{g}$./day. Folate excretion was raised in cirrhosis to $25 \cdot 8-55.0$ (mean $35.7 ; \mathrm{P}<0.01) \mu \mathrm{g}$./day and also in congestive cardiac failure at a range of $2.5-61.6$ (mean $26.9 ; 0.05>\mathrm{P}>0.02) \mu \mathrm{g}$./day.

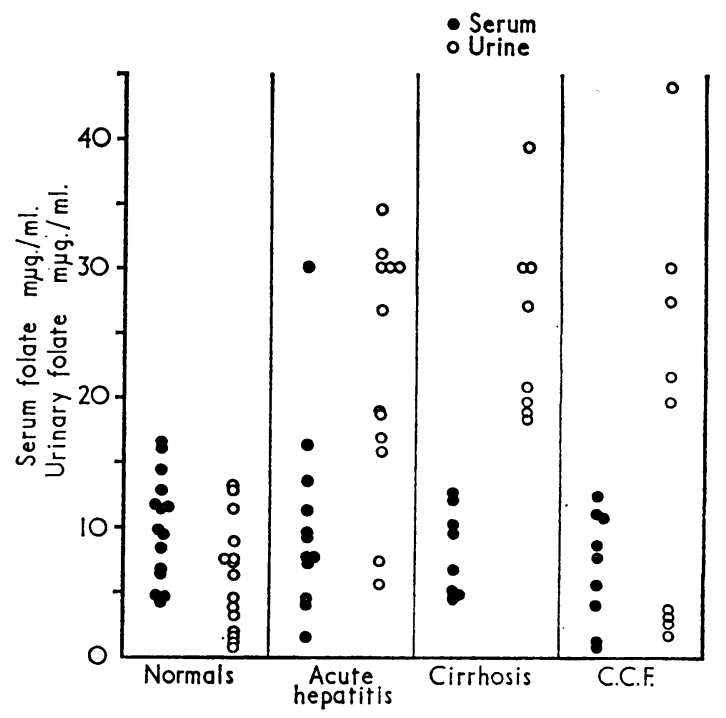

FIG. 1.-Serum and urinary folate levels in normal individuals and patients with acute hepatitis, cirrhosis, and hepatomegaly due to congestive cardiac failure (C.C.F.). Some subjects with hepatitis had urinary folate values reported as $>30 \mathrm{~m} \mu \mathrm{g} . / \mathrm{ml}$. ; these have becn graphed as

$$
30 \mathrm{~m} \mu \mathrm{g} . / \mathrm{ml} \text {. }
$$

(3) In Fig. 2 serum and urinary folate levels are correlated. There was no direct correlation. The highest urinary folate values were associated with the lowest serum folates.

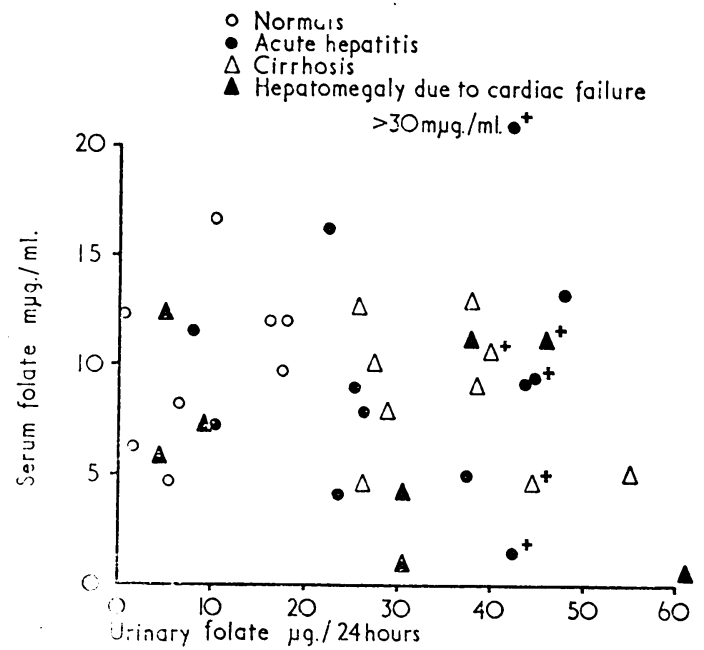

FIG. 2.- Serum folate correlated with daily urinary folate loss in normal individuals and patients with acute hepatitis, cirrhosis, and congestive cardiac failure with hepatomegaly. In some instances (values marked with crosses) urinary folate had been reported as $>30 \mathrm{~m} \mu \mathrm{g} . / \mathrm{ml}$. Total daily folate excretion was then calculated as for $30 \mathrm{~m} \mu \mathrm{g} . /$

(4) Serum and urinary folates, serum bilirubin and transaminases, and serum and urinary vitamin $B_{12}$ values obtained in the course of acute hepatitis in three patients are represented in Fig. 3. The increased urinary folate excretion returned to normal within a fortnight after the onset of illness, when recovery was uneventful. In two of these patients a low serum folate in the acute phase of the illness returned to normal 
during recovery of the hepatitis. Urinary vitamin $\mathrm{B}_{12}$ excretion was in excess of $250 \mu \mu \mathrm{g}$./ml. (upper limits of normal for this laboratory) only when serum vitamin $B_{12}$ was greater than $1,000 \mu \mu \mathrm{g} . / \mathrm{ml}$.
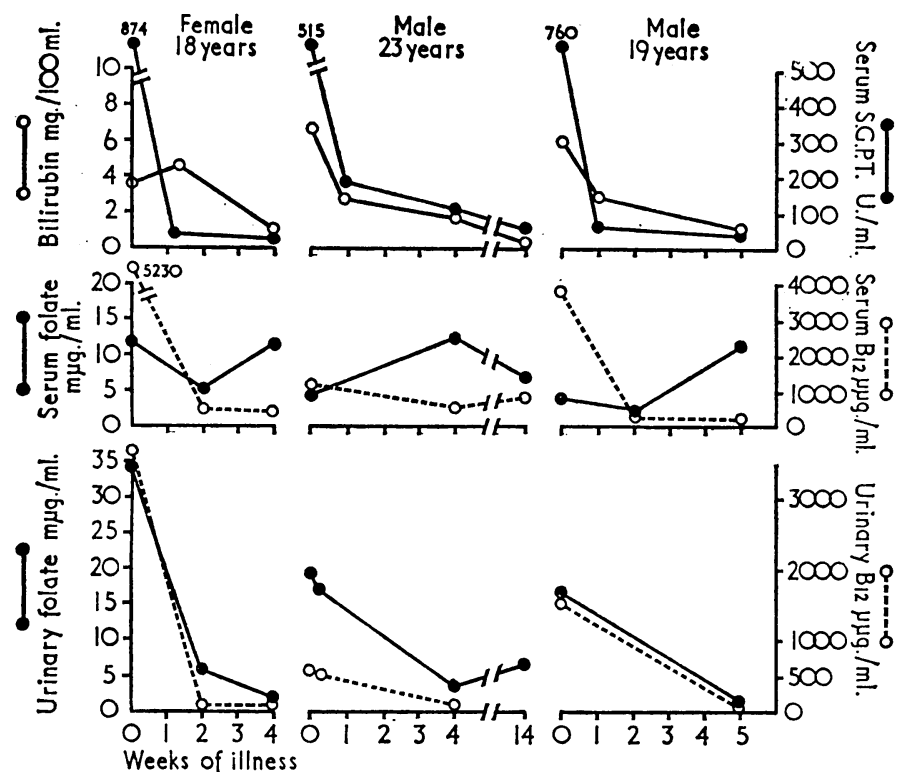

FIG. 3.- Serum and urinary folate and vitamin $\mathbf{B}_{12}$ levels obtained in three young adult patients with acute viral hepatitis. Recoveries were uneventful and serum bilirubin and serum alanine aminotransferase (S.G.P.T.) values are recorded as clinical criteria.

(5) In the dialysis experiments urinary folate fell maximally during the furst 6 to 12 hours of dialysis and in normals approached zero at 24 hours (Fig. 4). Clearance of folate from certain hepatitis urines appeared to be slower than from normal urine, but this could be ascribed to their much higher initial folate levels; at 72 hours mean values were $<1 \mathrm{~m} \mu \mathrm{g} . / \mathrm{ml}$. in all study groups (see Table). Serum folate decreased initially at a rate comparable with that of urine (Fig. 4). However, over the period of 24 to 72 hours serum folates stabilized on a baseline range well above that for urine. This level was comparable for normal and hepatitis serum (see Table). In two patients with cirrhosis clearance of serum and urinary folate followed a pattern rather similar to that of hepatitis.
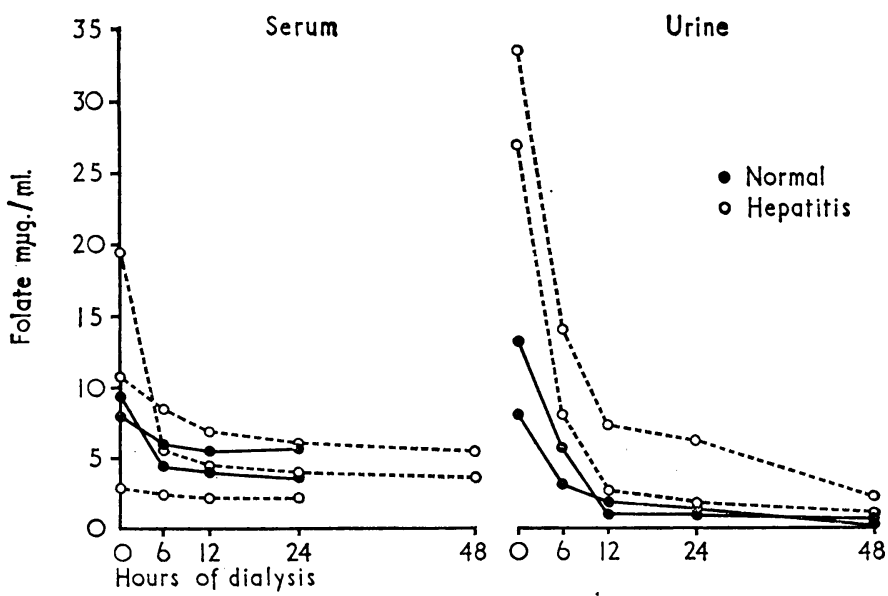

FIG. 4.-Effect of Visking casing dialysis (over 6, 12, 24, and 48 hours) on urinary and serum folate levels are recorded. Samples were obtained from normal individuals and subjects with acute hepatitis.

\section{Discussion}

At the onset of acute viral hepatitis urinary folate excretion may be considerable. In this study it reached $48 \cdot 3 \mu \mathrm{g}$. $/$ day. This was a temporary phenomenon lasting only as long as the active hepatitis persisted (Fig. 3) and is unlikely to cause serious folate depletion in a previously normal individual. Urinary folate loss, however, was also prominently increased in cirrhosis. In this chronic disease, commonly associated with defective dietary habits, prolonged urinary folate loss may be a significant drain on folate stores. Folate release from the cirrhotic liver probably relates to the activity of the cirrhotic process. Our patients were studied while in hospital for control of the disease, so that folate loss was possibly greater than in the symptomless quiescent cirrhotic. Considerable urinary folate loss and a low serum folate were also found with congestive hepatomegaly of cardiac failure. Cardiac failure is not a recognized cause of folate deficiency. The association may well be commoner than is realized, but reasonably adequate diet probably protects against gross folate depletion.

Little is known about the renal handling of folate in man. Johns et al. (1961) and Goresky et al. (1963) suggested that the kidneys have a limited ability to reabsorb folate by a membrane carrier-transport system, and that urinary folate clearance was independent of plasma folate above concentrations of about $10 \mu \mathrm{g} . / \mathrm{ml}$. In marked contrast with vitamin $\mathbf{B}_{12}$, which is strongly protein bound and appears in the urine in excessive amounts only when serum vitamin $B_{12}$ is very high (Retief et al., 1969), urinary folate levels bore no relation to serum folate levels in the present study (Fig. 2). Studies with pteroylmonoglutamic acid showed strong folic acid binders in milk (Ghitis and Lora, 1967 ; Metz et al., 1968) and weaker binders in serum (Metz et al., 1968). These serum binders, however, were not blocked by N5-methyltetrahydrofolate, the naturally occurring serum folate, and their physiological significance is thus uncertain.

The finding that serum folate is largely cleared by charcoal (Herbert et al., 1962), rapidly dialysed through a cellulose membrane (Condit and Grob, 1958), and probably lowered by artificial kidney dialysis (Hampers et al., 1967) suggested poor folate binding by serum proteins. Excessive urinary loss of folate in spite of low serum levels in hepatic disease (Fig. 2) may theoretically be ascribed to a liver binder of folate which enters the blood stream during liver damage and is selectively lost through the kidneys. A fall in plasma folate, however, is an early sign of negative folate balance, and it normally precedes significant depletion of folate stores (Herbert, 1962). A low serum and high urinary folate could thus indicate an early stage of folate depletion, with still adequate liver stores.

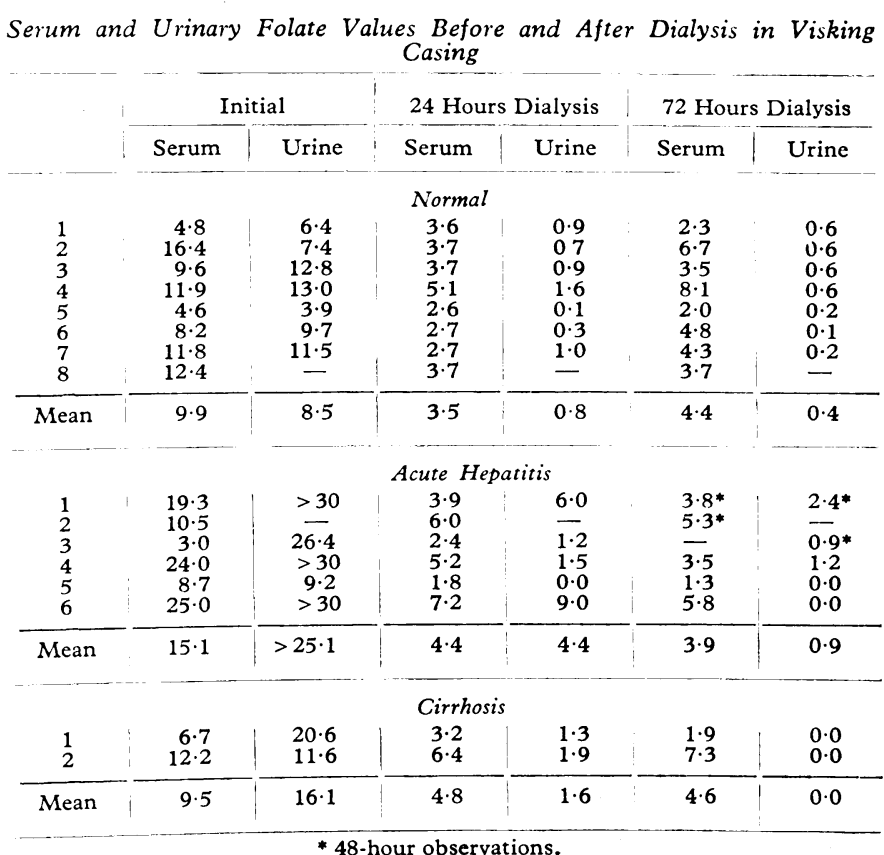


During saline dialysis in Visking casing folate was rapidly and almost completely dialysed from urine, but a fraction of the serum folate persisted in spite of prolonged dialysis. This suggests that serum folate normally exists as free and proteinbound fractions. Similar initial disappearance rates for urinary and serum folates (Fig. 4) may indicate that urinary folate is unbound and derived from the free plasma folate fraction. The non-dialysable serum folate fraction, which probably represents protein-bound folate, was comparable in normal serum and liver disease, in spite of marked differences in initial total folate levels (see Table). These preliminary results supply no evidence that the folate binder in liver disease differs from that in normal serum. Folate may thus be liberated from the diseased liver in the free form with a variable effect on serum folate levels, depending on the speed with which free folate is cleared by the kidney and the magnitude of folate liberation.

We wish to thank Professor A. J. Brink (Department of Internal Medicine, Stellenbosch University Medical School) for supplying the necessary research facilities. The project was supported by a grant from the South African Council for Scientific and Industrial Research.

\section{REFERENCES}

Baker, H., Frank, O., Ziffer, H., Goldfarb, S., Leevy, C. M., and Sobotka, H. (1964). American fournal of Clinical Nutrition, 14, 1. Carter, F. C., Heller, P., Schaffner, G., and Korn, R. J. (1961). Archives of Internal Medicine, 108, 41.
Chanarin, I., Hutchinson, M., McLean, A., and Moule, M. (1966). British Medical fournal, 1, 396.

Condit, P. T., and Grob, D. (1958). Cancer (Philadelphia), 11, 525.

Ghitis, J., and Lora, C. (1967). American fournal of Clinical Nutrition,

Goresky, C. A., Watanabe, H., and Johns, D. G. (1963). fournal of Clinical Investigation, 42, 1841 .

Hampers, C. L., Streiff, R., Nathan, D. G., Snyder, D., and Merrill, J. P. (1967). New England Fournal of Medicine, 276, 551.

Herbert, V. (1962). Transactions of the Association of American Physicians, 75, 307.

Herbert, V. (1965). In Progress in Liver Disease, vol. 2, edited by $\mathrm{H}$. Popper and F. Schaffner, p. 57. London, Heinemann.

Herbert, V. (1966). Fournal of Clinical Pathology, 19, 12

Herbert, V., Larrabee, A. R., and Buchanan, J. M. (1962). fournal of Clinical Investigation, 41, 1134.

Herbert, V., Zalusky, R., and Davidson, C. S. (1963). Annals of Internal Medicine, 58, 977.

Johns, D. G., Sperti, S., and Burgen, A. S. V. (1961). Fournal of Clinical Investigation, 40, 1684 .

Klipstein, F. A., and Lindenbaum, J. (1965). Blood, 25, 443.

Lau, K. S., Gottlieb, C., Wasserman, L. R., and Herbert, V. (1965) Blood, 26, 202.

Merritt, A. D., Rucknagel, D. L., Silverman, M., and Gardiner, R. C. (1962). Fournal of Clinical Investigation, 41, 1472

Metz, J., Zalusky, R., and Herbert, V. (1968). American fournal of Clinical Nutrition, 21, 289.

Retief, F. P., Heydenrych, J. J., and Murphy, G. P. (1968). South African Medical fournal, 42, Suppl., 17 August, p. 13

Retief, F. P., Vandenplas, L., and Visser, H. (1969). British fournal of Haematology, 16, 231.

Stevenson, T. D., and Beard, M. F. (1959). New England fournal of Medicine, 260, 206.

Sullivan, I.. W., and Herbert, V. (1964). Journal of Clinical Investigation, ' 3, 2048.

\title{
Application of Urine Analysis to Diagnosis and Treatment of Heroin Addiction
}

\author{
VINCENT MARKS,* B.M., M.R.C.P.ED., M.C.PATH. ; DENYS FRY,† B.SC. P. A. L. CHAPPLE, $\ddagger$ M.B., CH.B., D.P.M. \\ GEOFFREY GRAY,§ M.B., B.S.
}

\begin{abstract}
ummary : Experience with urine analysis for morphine using thin-layer chromatography in $\mathbf{3 1 0}$ cases of real or possible heroin abuse showed that it was valuable not only in detecting improper drug use but also in monitoring treatment. The results of this test can be available routinely in 24, and exceptionally in five hours. A negative result implies that the subject has taken less than $10 \mathrm{mg}$. of heroin in the past 24 hours.
\end{abstract}

\section{Introduction}

Until 1963 heroin addiction was a relatively minor problem in the U.K. There is still little reliable information on the value of clinical biochemistry in the diagnosis and management of this disorder, though its potential importance has been recognized by the Department of Health and Social Security, which has taken steps to provide laboratory facilities for each of its recently inaugurated drug dependency treatment units.

This paper records experience with urine analysis for heroin (as morphine) in 310 cases of real or possible heroin abuse.

\footnotetext{
* Consultant Chemical Pathologist, West Park Hospital, Epsom, Surrey.

$\ddagger$ Principal Biochemist, West Park Hospital, Epsom, Surrey. S.W.3.
}

Chairman, National Addiction and Research Institute, London S.W.3.
Laboratory investigations (Marks, 1966 ; Marks and Chapple, 1967 ; Marks and Fry, 1968) were carried out on 310 patients misusing or claiming to be misusing heroin. All had come under the clinical care of one of us (P.A.L.C.) at some time during the four-year period 1964-8, either as an outpatient attending one of several hospitals in the Metropolitan Area or latterly at the National Addiction and Research Institute, Chelsea. Most were seen on at least two occasions, and several upwards of 100 times. Age and sex, as recorded on the first laboratory request form, are shown in the Table. Only those patients (a) from whom urine was collected for analysis on their first consultation for real or alleged drug misuse or $(b)$ from whom at least four urine specimens were analysed during a period of not less than four months, and in whom heroin withdrawal (with or without substitution therapy) was attempted, are considered further in this paper.

None of the patients was (or claimed to be) using heroin alone. Before 1967 most were regularly taking cocaine as well as heroin, and, generally, though more sporadically, other drugs such as amphetamines, barbiturates, and cannabis. During the past year (1967-8) methylamphetamine has almost completely by the majority of heroin abusers. 